Creative Commons License: CC BY-SA 4.0

https://creativecommons.org/licenses/by-sa/4.0/deed.en

\author{
Ewelina Głowacka \\ Wydział Filologiczny \\ Uniwersytet w Białymstoku \\ e-mail: eweli.glowacka@gmail.com \\ ORCID: 0000-0003-0068-8098
}

\title{
Wspólnota rozszerzona
}

Ekokrytyka na gruncie polskiego literaturoznawstwa pojawiła się $\mathrm{z}$ dużym opóźnieniem $\mathrm{w}$ porównaniu $\mathrm{z}$ literaturoznawstwem angloamerykańskim, a kiedy już w nim zaistniała, przyjmowała się opornie. Pisze o tym Jarosław Woźniak w swoim artykule Widma ekokrytyki ${ }^{1}$, w którym referuje losy tego nurtu począwszy od artykułu Jerzego Madejskiego Przyboś ekokrytyczny² z 2002 roku, którego znaczną część stanowiło przybliżenie metodologii ekokrytycznej. Jako następną pozycję badacz wymienia $\mathrm{Cy}$ borga w ogrodzie Julii Fiedorczuk (w pierwszej wersji z 2002 roku we współpracy z Grzegorzem Jankowiczem, później w formie książkowej z 2015 roku), a także artykuły Justyny Tabaszewskiej ${ }^{3}$ (2010; 2011), od razu jednak wskazuje zawarte $w$ nich błędy i ocenia je jako regresywne względem wcześniejszej literatury naukowej. W ostatnich latach czołową badaczką studiów nad zwierzętami w Polsce stała się Anna Barcz, jako autorka publikowanych od 2011 roku licznych artykułów ${ }^{4}$, redaktorka dwóch monografii: Zwierzęta,

\footnotetext{
1 J. Woźniak, Widma ekokrytyki, „Przestrzenie Teorii” 2017, nr 28, s. 169-191.

2 J. Madejski, Przyboś ekokrytyczny?, w: Stulecie Przybosia, red. S. Balbus, E. Balcerzan, Poznań 2002.

3 J. Tabaszewska, Jedna przyroda czy przyrody alternatywne? O pojmowaniu i obrazach przyrody w polskiej poezji, Kraków 2010; Zagrożenia czy możliwości? Ekokrytyka - rekonesans, „Teksty Drugie” 2011, nr 3.

4 A. Barcz, O ciele ekokrytycznie i z perspektywy queer, „Przegląd Filozoficzno-Literacki” 2011, nr 4, s. 215-231; Przyroda - bliska czy daleka? Ekokrytyka i nowe sposoby poetyki odpowiedzialności za przyrode w literaturze, "Anthropos?” 2012, nr 18-19, s. 59-79; Posthumanizm i jego zwierzęce
} 
gender, kultura ${ }^{5}$ (2014) oraz Zwierzęta i ich ludzie ${ }^{6}$ (2015), a także autorka książki Realizm ekologiczny. Od ekokrytyki do zookrytyki w literaturze polskiej7 (2016). Warto wymienić także monografię Piotra Krupińskiego "Dlaczego gęsi krzyczały?"8 (2016) łączącą perspektywę studiów nad Zagładą i studiów nad zwierzętami. W 2017 roku ukazała się książka Beaty Mytych-Forajter Zwierzęta na zakręcie ${ }^{9}$, stanowiąca antologię tekstów romantycznych i będąca częścią serii Nowa Biblioteka Romantyczna Instytutu Badań Literackich PAN. W tym samym roku wyszła monografia Anny Filipowicz (Prze)zwierzęcenia. Poetyckie drogi do postantropocentryzmu ${ }^{10}$, a w roku 2018 ukazał się numer „Tekstów Drugich" zatytułowany Ekokrytyka ${ }^{11}$.

Obszar polskich badań ekokrytycnych w interesujący sposób poszerza Anita Jarzyna w książce Post-koiné. Studia o nieantropocentrycznych językach (poetyckich) ${ }^{12}$, poddając analizie narracje nieantropocentryczne pojawiające się we współczesnej poezji polskiej. Autorka przygląda się narzędziom, jakie stosują poeci i poetki, by ująć rzeczywistość z perspektywy poszerzonej, innej niż ludzka. Interesują ją także poetyckie metarefleksje na temat samych możliwości uchwycenia takiej pozaludzkiej perspektywy oraz próby stworzenia odpowiedniego do jej wyrażenia języka. Poszukuje w poezji śladów komunikacji międzygatunkowej, tropi znaki uważności poetów na mowę inną niż słowo czy gest, na niekonwencjonalne przekazy, charakterystyczne dla zwierząt, na przykład wyrażane i odbierane na poziomie węchowym. Pytanie o płaszczyznę porozumienia międzygatunkowego jest w Post-koiné stawiane na różnych, nieraz zaskakujących, poziomach. Jarzyna analizuje także kulturowe narracje o zwierzętach, które niosą w sobie ukrytą opresję i antroponormatywną przemoc.

odgłosy w literaturze, „Teksty Drugie” 2013, nr 1-2, s. 60-79; "Moja przyjaciótka krowa” - o niesymbolicznej reprezentacji krowy u Julii Hartwig, Jolanty Brach-Czainy i Marlen Haushofer, w: Ludzie i zwierzęta, red. R. Chymkowski, A. Jaroszuk, Warszawa 2014, s. 101-116; Wprowadzenie do zookrytyki (teorii zwierzęcych narracji), „Białostockie Studia Literaturoznawcze” 2015, nr 6, s. 143-159.

5 Zwierzęta, gender, kultura. Perspektywa ekologiczna, etyczna i krytyczna, red. A. Barcz, M. Dąbrowska, Lublin 2014.

6 Zwierzęta i ich ludzie. Zmierzch antropocentrycznego paradygmatu?, red. A. Barcz, D. Lagodzka, Warszawa 2015.

7 A. Barcz, Realizm ekologiczny. Od ekokrytyki do zookrytyki w literaturze polskiej, Katowice 2016.

8 P. Krupiński, "Dlaczego gęsi krzyczały?" Zwierzęta i Zagłada w literaturze polskiej XX i XXI wieku, Warszawa 2016.

9 B. Mytych-Forajter, Zwierzęta na zakręcie, Warszawa 2017.

10 A. Filipowicz, (Prze)zwierzęcenia. Poetyckie drogi do postantropocentryzmu, Gdańsk-Sopot 2017.

11 „Teksty Drugie” 2018, nr 2.

12 A. Jarzyna, Post-koiné. Studia o nieantropocentrycznych językach (poetyckich), Łódź 2019. 
Oprócz samego tematu, intrygujący jest również ze względu na swoją nieoczywistość wybór utworów, które badaczka zdecydowała się omówić w kontekście ekokrytycznym. Jarzynę interesują przebłyski perspektywy nieantropocentrycznej $\mathrm{u}$ autorów, którzy nie są bezpośrednio kojarzeni z nurtem ekokrytycznym. Jak sama wyjaśnia: „zamysł i ramy niniejszej książki nie obejmują twórczości poetów i poetek wywodzących się z paradygmatu postantropocentrycznego, jednoznacznie się z nim identyfikujących, składających w wierszach ideowe deklaracje, konsekwentnie rozmontowujących ludzki podmiot" [s. 48] ${ }^{13}$. Autorka wybiera dzieła, w których nieantropocentryczne treści są marginalne, pojawiają się $\mathrm{w}$ pojedynczych utworach i „nie zawsze są przejawem konsekwentnie emancypacyjnego nieantroponormatywnego światopoglądu poetyckiego" [s. 48]. Skupia się na "swego rodzaju poetyckich zwiastunach krytycznej świadomości, niejednorodnych prekursorskich wyłomach $w$ dotychczasowej wizji relacji międzygatunkowych, symptomach nadchodzącej zmiany" [s. 49]. Próbuje zatem badać nieuświadomione zmiany zbiorowej wyobraźni w zakresie myślenia o zwierzętach, stawiając sobie za cel zbudowanie „problemowej mapy zjawiska” [s. 48], którego istotą miałaby być głęboka przemiana języka.

Obszerna, ponad pięśsetstronicowa książka dzieli się na cztery bloki tematyczne, z których każdy zawiera szczegółowe podrozdziały. Część pierwsza, Innymi słowy, ogniskuje się wokół specyfiki perspektywy nieantropocentrycznej. Rozdział rozpoczynający tę część, a zarazem całą książkę, Wprowadzenie do post-koiné, pełni funkcję wstępu, zapowiadającego kolejne segmenty i przybliżającego czytelnikowi tytułowe pojęcie. Starogreckie koiné, oznaczające język wspólnoty obcy barbarzyńcom, staje się kanwą dla stworzenia nowego, bardziej inkluzywnego sposobu komunikacji. Idea post-koiné to próba poszerzenia ludzkiej wspólnoty językowej o świat innych gatunków zwierząt niż człowiek, znalezienia "szerszej - otwartej, międzygatunkowej, niestabilnej - formuły" [s. 42]. Towarzyszy temu przekonanie autorki, że ,język jest zdolny wychylać się poza ludzkie kategorie" [s. 30]. Rozważania w omawianej części koncentrują się wokół dwóch biegunów - mowy i jej braku, są próbą rozmontowania binarnej opozycji człowiek-zwierzę.

Częstym zarzutem wobec narracji nieantropocentrycznych jest podkreślanie ich utopijności podbudowane przekonaniem o niemożliwości wykroczenia człowieka poza ludzką perspektywę. Problem ten Jarzyna traktuje

13 Jarzyna wskazuje autorów cechujących się wrażliwością nieantropocentryczną: Kirę Pietrek, Ilonę Witkowską, Kacpra Bartczaka, Szczepana Kopyta i Michała Czaję. Badaczka uzasadnia ten wybór potrzebą użycia w obu przypadkach - tj. poezji programowo postantropocentrycznej i poezji, w której takie wątki pojawiają się mimochodem - osobnych kategorii opisu. 
jako „immanentną cechę "post-koiné»”, a więc języka stroniącego od przeświadczenia o własnej wszechmocy, i w związku z tym deklaruje, że w polu jej zainteresowania znajdują się również przypadki, w których autorzy i autorki tematyzują własne poczucie bezradności językowej i nieudane poetyckie próby "sprostania pewnym postulatom dyskursów postantropocentrycznych" [s. 51]. Utworem, który świetnie to oddaje i który stał się niejako mottem omawianej książki, jest wiersz „powinien" Krystyny Miłobędzkiej. Utwór ten przewiduje język, jakim można by było mówić o zwierzętach, podaje nieśmiałe poglądowe przykłady, ale wciąż pozostaje jedynie projektem tego, jak mogłaby wyglądać nieantropocentryczna poezja, zachowuje charakter „permanentnie preliminarny” [s. 39], poetka niejako „afirmuje niemożliwość, o jakiej opowiada" [s. 39]. O tym paradoksie języka mówi także przywoływany wielokrotnie przez Jarzynę Tadeusz Sławek: „Stawką jest język, który nie utwierdza we wszechmocy precyzji języka, język, który od wewnątrz powątpiewa w zdolność języka do osiągania celu" [s. 12].

Interesujące jest także przypomniane przez badaczkę porównanie poematu do jeża, poczynione niegdyś przez Jacquessa Derridę, a później komentowane także przez Tadeusza Sławka. Porównanie to opiera się na obserwacji, że zwierzę i wiersz działają podobnie na wyobraźnię człowieka: „wiersz, «mowa najeżona trudnościami, wieloznacznościami» odkształca język" [s. 29] w obawie przed jego spłyceniem i dewaluacją, podobnie jak zwierzę, które wystawia kły i pazury, w obawie przed skrzywdzeniem. W jednym i drugim przypadku oswojenie zapewnia inny, nieprzemocowy rodzaj relacji. Kwestia językowej przemocy wobec zwierząt jest także omawiana przez badaczkę, wyraźnie podkreślającą, że to, jak mówimy, przekłada się bezpośrednio na to, jak działamy: „przyzwolenie na zabijanie pewnej grupy istot zaczyna się w języku, w eufemizmach maskujących przemoc" [s. 28]. Zwierzęta, podobnie jak ludzie, podlegają mowie nienawiści i chociaż nie zawsze ją pojmują, dotkliwie doświadczają jej skutków.

Rozdział Kim jesteśmy My i kim sa One? Notatki o jednym wierszu Andrzeja Niewiadomskiego omawia niezwykle ciekawy koncept rozpoznawania w sobie śladów poprzednich ogniw ewolucji. Niewiadomski, jak pisze Jarzyna, „podejmuje [...] imaginacyjne próby rozeznania przedludzkiej podmiotowości, wyłaniania się z niej człowieka" [s. 64]. Podobne refleksje zawarte są w wierszu Jacka Podsiadły, także przytoczonym przez autorkę i przeanalizowanym za pomocą kategorii pamięci ciała oraz odnajdywania własnej tożsamości: „poznanie siebie jest rozpoznaniem pokrewieństw międzygatunkowych, wyobraźniowym ruchem w ich stronę" [s. 63]. Kontekstem tych krytycznoliterackich analiz, oscylujących wokół ewolucji i laboratoriów, jest etyczny problem badań prowadzonych na zwierzętach. Tym samym uwydatnia się 
tu bardzo ważna cecha myślenia ekokrytycznego, a mianowicie jej społeczno-polityczne zaangażowanie, potrzeba, by rozważaniom krytycznoliterackim towarzyszyła również refleksja etyczna.

Szczególnie interesujący jest rozdział Dzieci i ryby (wiersze na głosy), w którym badaczka zwraca uwagę na pewne pęknięcie istniejące w kulturze, polegające na tym, że dzieci, poprzez oficjalne narracje, przysposabiane są do życia w moralnym rozdwojeniu: $\mathrm{z}$ jednej strony mówi się im o poszanowaniu dla żywych istot, z drugiej - dopuszcza się tak oczywiste formy dręczenia zwierząt, jak jedzenie mięsa, więzienie zwierząt $w$ ogrodach zoologicznych, czy zabijanie owadów. Świetnie obrazuje to w poezja dziecięca, którą przytacza Jarzyna, komentując w ten sposób: „często utwory dla dzieci wzmacniają mechanizmy ignorowania i oswajania figur i obrazów opresji nad zwierzętami” [s. 84]. W literaturę dziecięcą wpisane jest „przyzwolenie na przemoc zakodowaną $w$ grach słownych oraz dysonans powstający między wpajanym dzieciom przekonaniem, że nie należy krzywdzić zwierząt, a przedstawieniami legitymizującymi antroponormatywne praktyki opresji" [s. 89]. Samozwańcze hierarchizowanie przez człowieka wartości życia poszczególnych gatunków wynika z antropocentrycznych wzorców kulturowych, które są reprodukowane $w$ utworach dla najmłodszych, nawet tych pozornie oswajających dzieci z przyrodą.

Kolejna część, Stany wyjątkowe, status quo, dotyczy rozważań w obszarze „animalno-zagładowego imaginarium” [s. 48] i opiera się na obserwacji, że studia nad Zagładą zazębiają się ze studiami nad zwierzętami poprzez kategorie animalizacji czy dehumanizacji, a także segregacji istot na te „przydatne" i te "zbędne”, czy wręcz „szkodliwe”. Niezwykle zaskakującą i odważną myśl prezentuje rozdział dotyczący masakry stambulskich psów z 1910 roku, w którym wydarzenie to zestawione zostaje z późniejszą o 5 lat rzezią Ormian. Jarzyna stawia tezę, że decyzja skazania na śmierć setek bezpańskich psów realnie przekładała się na późniejszą decyzję o ludobójstwie Ormian. Zadziałał w tym przypadku mechanizm wytwarzania binarnej opozycji człowiek-inne gatunki, poddanej jednak modyfikacji, w wyniku czego do kategorii drugiej została przesunięta arbitralnie wybrana grupa ludzi, w tym wypadku Ormianie, w innym, jak podczas Shoah - Żydzi.

W rozdziale omawiającym wiersz [TAKŻE TOBIE, o mój ukochany] Nelly Sachs Jarzyna zauważa i opisuje bardzo interesujące zjawisko. Jako że polski przekład tego wiersza autorstwa Ryszarda Krynickiego jest późniejszy od oryginału o sześćdziesiąt lat, jego polska wersja zostaje poniekąd wrzucona w nowy społeczno-literacki kontekst, dzięki czemu utwór zyskuje dodatkowe znaczenia. Tym specyficznym kontekstem jest nieantroponormatywny konstrukt „holokaustu zwierząt", który najprawdopodobniej nie był pierwot- 
nie intencją Sachs, a którego przywołanie trudne jest do uniknięcia podczas czytania omawianego wiersza współcześnie. Utwór wyraża ból po stracie ukochanego i opisuje moment, kiedy niemieccy żołnierze po uśmierceniu mężczyzny ściągają mu ze stóp buty z cielęcej skóry. Poetka, wspominając to straszne wydarzenie, ma w sobie dość wrażliwości i otwarcia, by pamiętać, że zanim tę skórę, którą kiedyś lizał czule język matki-krowy, ściągnięto z nóg ukochanego, wcześniej ściągnięto także z cielęcia. Poprzez tę analogię, jak twierdzi Jarzyna, poetka nie tylko ukazuje międzygatunkową wspólnotę odczuwania bólu i cierpienia, ale także podkreśla przynależną ssakom potrzebę bliskości. W tej optyce znika deprecjonujący wydźwięk takich porównań [s. 144]. Jarzyna wydobywa też macierzyński rys miłości w utworach Sachs, jaki implikuje analogia pomiędzy losem krowy, która straciła cielaka, a losem poetki, która straciła ukochanego. Uwzględnienie czułości okazywanej sobie nawzajem przez zwierzęta oraz opisywanie więzi, jakie tworzą, zapobiega ich wiktymizacji, sprowadzeniu jedynie do roli cierpiących ofiar. W miejsce skutecznie skompromitowanego w wyniku wojen człowieczeństwa wiersz proponuje „wcześniejsz[ą] od niego, elementarn[ą] potrzeb[ę] bliskości" [s. 157].

W rozdziale Życie ptaków i ssaków po zagadnienie "holokaustu zwierząt” zostaje nieco bardziej sproblematyzowane. Na podstawie wybranych wierszy powstałych po 1989 roku, dotyczących Zagłady, a w jej kontekście także stosunku człowieka do zwierząt, Jarzyna wyciąga wnioski, że analogia pomiędzy hodowlą przemysłową a mechanizmami Zagłady straciła swoją pierwotną moc, uległa leksykalizacji, została „oswojona w wyobraźni oraz pamięci zbiorowej" [s. 236], a zatem nie spełnia już swojej funkcji.

Kolejne studium z omawianego działu dotyczy zjawiska "Judenjagd", czyli "polowania na Żydów” i ukazuje, w jaki sposób język nazistowskich Niemiec czerpał z socjolektu myśliwsko-łowieckiego w sposobie mówienia o ludności żydowskiej. W odniesieniu do Żydów funkcjonowały terminy, takie jak „nagonka”, „zabijanie Żydów jak kaczki”, czy też „strzelanie Żydów" (z pominięciem "do", podczas gdy w odniesieniu do innych nacji używano sformułowania z przyimkiem). Niekiedy obok miejsc kaźni przeprowadzanej na Żydach „stał stolik z zakąskami i wódką" [s. 174], co swoją formułą przypominało myśliwskie biesiady odbywające się $\mathrm{w}$ czasie pokotu. Podobny język stosowany był również wobec partyzantów, którym przypisywano zdziczenie i brutalność, określano ich mianem „zwierzyny”, którą należy "wytropić" i zabić.

Co ciekawe, nawet sami prześladowani utożsamiali się z leśnymi zwierzętami, choć zupełnie na innym poziomie - łączyło ich poczucie strachu i zagrożenia, przymus ukrywania się i stałej czujności. To poczucie strachu 
było doświadczeniem tak silnym, że różnice gatunkowe okazywały się rzeczą drugorzędną [s. 185], pojawiła się więc możliwość międzygatunkowej „wspólnoty doświadczającej sytuacji granicznej” [s. 189]. Kontekst analiz Jarzyny stanowi przytoczona przez nią relacja, że niemalże $w$ tym samym czasie uchwalone zostały $w$ Niemczech przepisy dotyczące praw zwierząt (prawo o ochronie zwierząt, prawo ograniczające polowania i prawo o ochronie natury) oraz ustawy norymberskie. Jednak od początku te pierwsze naznaczone były skrajnym rasizmem, uchwała dzieliła bowiem zwierzęta na takie, którym rzeczywiście przysługują jakieś prawa, i na gatunki uznawane za "szkodniki”.

W rozdziale Szlemiele. Zwierzęta wobec Zagłady w literaturze dla dzieci badaczka omawia dzieła, w których zwierzęta towarzyszące człowiekowi zyskują sprawczość, stają się towarzyszami broni i pomagają $\mathrm{w}$ działaniach konspiracyjnych: spacer z psem Szlemielem, bohaterem powieści Ryszarda Marka Grońskiego, ułatwiał rozwieszanie ulotek Polski Walczącej. Czworonóg pomógł także wyprowadzić z getta Joasię oraz uchronił dziewczynkę przed szmalcownikiem [s. 212]. Z kolei w opowieści o Irenie Sendlerowej suczka Szepsi pomaga swoim szczekaniem w wywożeniu dzieci z getta, zagłuszając ich płacz [s. 212]. Zaś w powieści Joanny Rudniańskiej, tytułowa kotka zmyliwszy psa gestapowców, ratuje skrywającego się Żyda [s. 212]. Zwierzęta stają się także ofiarami antysemityzmu - pies żydowski miał znacznie mniejsze szanse na to, że ktoś nim się zajmie, od psa nieżydowskiego [s. 201]. Jarzyna na tych przykładach pokazuje jednak, że narracje prowadzone z perspektywy zwierzęcia niosą za sobą powracające zagrożenie, bowiem samo udzielenie głosu Szlemielowi nie powoduje automatycznego uwolnienia go od „ludzkich rozróżnień, podziałów, perspektyw” [s. 213]. Badaczka ma wątpliwości, "czy antroponormatywny język zostaje w tej powieści dostatecznie naruszony" [s. 213], ponieważ to losy opiekunów psa i ich doświadczenie wojny determinują jego narrację.

Trzecia część Post-koiné o tytule Obyczaje „poświęcona jest gestom demaskacji praktyk opresji wobec zwierząt, wpisanych w kulturę, obyczaje, więc społecznie aprobowanych, swoiście legitymizowanych w języku" [s. 48]. Autorka zaznacza, że świadomie pomija w swojej książce bardzo ważny wątek przemocy wobec zwierząt w języku chłopskim i kulturze ludowej, bowiem jest to obszar na tyle rozległy, że należałoby mu poświęcić osobną publikację. Rozdział zaczynający tę część rozprawy poświęcony jest zwierzęcym „herezjom” w poezji Tadeusza Nowaka oraz w publicystyce Jerzego Nowosielskiego. Wizje obu artystów dotyczące mistycznego statusu istot pozaludzkich w świecie są ze sobą zbieżne i można by umiejscowić je w nurcie teologii 
zwierząt. Tradycyjna nauka Kościoła, jak wykazuje Jarzyna, pomimo deklarowanego poszanowania dla zwierząt, jest w swej istocie dogłębnie antropocentryczna. Pewne zmiany w tym temacie przynosi encyklika Laudato si' papieża Franciszka mówiąca o ekologii integralnej, a więc takiej, która sytuuje człowieka „nie ponad przyrodą, lecz w sieci powiązań, co znaczy, że winien on brać odpowiedzialność za ekosystem, w którym żyje" [s. 278], nie znosi ona jednak hierarchizacji istnień według gatunku. Nowosielski, uznający Kościół instytucjonalny za twór archaiczny, wierzył w wykraczający poza Nowy Testament Kościół Ducha [s. 291], a w jednym z wywiadów zwiastuje dokonujący się obecnie „koniec chrześcijaństwa typowo antropocentrycznego" [s. 273]. Malarz uznaje zwierzę za "metafizyczn[ego] partner[a] człowieka" [s. 292], a nawet domniemywa, ,że zwierzęta są to cierpiące anioły, biorące udział w kenozie chrystologicznej" [s. 293]. Jarzyna w swojej analizie wydobywa głębokie związki pomiędzy filozofią Nowosielskiego a poetycką wyobraźnią Nowaka.

Poezja Tadeusza Nowaka zostaje omówiona również w następnym rozdziale tej części, tym razem w zestawieniu z twórczością Jerzego Ficowskiego. Badaczka zauważa, że poetów łączy ",bezkompromisowa niezgoda na hipokryzję języka" [s. 301] i ten wątek czyni osią swojej analizy. Sposób pisania obu twórców o zwierzętach uznaje za interwencyjny, sprzeciwiający się językowemu przetwarzaniu ciał zmarłych zwierząt na rodzaje mięsa [s. 309]. To zdemaskowanie eufemizmów wyraża głęboki sprzeciw wobec fałszu języka i jego antropocentryzmu, a przede wszystkim „otrzeźwia [...] ludzką wyobraźnię" [s. 310].

Studium Wolność powie: „krew” również dotyczy eufemizowania opresji wobec zwierząt, tym razem na przykładzie socjolektu myśliwskiego. Autorka $\mathrm{w}$ znacznej mierze opiera się tutaj na książce byłego myśliwego, Zenona Kruczyńskiego, pod znamiennym tytułem Farba znaczy krew, poświęconej wieloaspektowej krytyce łowiectwa. Jarzyna przytacza obnażoną przez Kruczyńskiego hipokryzję sformułowania "etyka łowiecka” oraz całego słownika myśliwskiego maskującego przemoc, jak na przykład tytułowa "farba", która oznacza krew postrzelonego zwierzęcia; „zestrzał” oznaczający ",sierść, krew, treść jelit lub kawałek kości czy wątroby na trawie" [s. 316] w miejscu postrzału; "badyl” oznaczający nogę jelenia; „komora” oznaczająca tułów, "fajki" oznaczające kły dzika czy „latarnia” oznaczająca głowę wilka [s. 316]. Podobnego rodzaju zabiegi Jarzyna interpretuje albo jako oznaki zobojętnienia, albo jako „dopiero środek znieczulający” [s. 317]. Krytykę takiego rodzaju eufemizowania okrucieństwa badaczka znajduje również w poezji i w twórczy sposób omawia Polowanie na cietrzewie Stanisława Grochowiaka, poemat intrygujący i niejednoznaczny. 
Rozdział Pomiotki. Czytajac Justyne Bargielska i Joannę Mueller dotyczy analogii ludzko-zwierzęcych w doświadczeniu macierzyństwa. Jarzyna dostrzega u obu twórczyń ,ślady afirmatywnego utożsamienia z samicami innych gatunków" [s. 335], a ponieważ ciężarna kobieta bywa uprzedmiotawiana i odczłowieczana poprzez pogardliwe porównania animalne („,dojna krowa”, „kwoka”), zdaniem badaczki, „subwersywne przejęcie owego dyskursu" [s. 335] pełni funkcję emancypacyjną, ponieważ dzięki niemu negatywne skojarzenia zwierzęcych inwektyw zostają rozbrojone. Tytułowa figura „pomiotki" to propozycja "podmiotowości otwartej, znoszącej przemocowe skojarzenia" [s. 335]. Jako że w płodność wpisane jest nie tylko rodzenie, ale też ronienie, druga część tekstu poświęcona jest właśnie temu zagadnieniu. Badaczka analizuje zjawisko "animalizacji ludzkiego zarodka” [s. 342] i zauważa zbieżność statusu zarodka jako ",jeszcze-nie-człowieka" ze statusem zwierzęcia jako „zawsze-nie-człowieka” [s. 342]. Opisuje też sposób, w jaki poetki uwalniają się z języka, w którym „to, co biologiczne, zostało upodrzędnione, zwrócone przeciw zwierzętom i kobietom, wpędzając je w rolę ofiary" [s. 357].

Łajka na dobranoc to interesujące studium zjawiska zwierzęcego celebrytyzmu, którego doskonałym przykładem była pierwsza psica w kosmosie. Od początku wysłaniu Łajki w kosmos towarzyszyła silna wieloletnia propaganda próbująca narzucić interpretację losów suczki oraz innych zwierząt o podobnej biografii - „nadawano [im dop. - E.G.] ludzkie cechy, eksponowano gotowość do poświęcenia oraz odwagę, odwracając uwagę od faktu, że po prostu je wykorzystywano" [s. 374]. Narracja przedstawiająca Łajkę jako superbohaterkę z powodzeniem przeniknęła do popkultury. Powstało mnóstwo książek dla dzieci opowiadających o przygodach Łajki, pocztówek i znaczków pocztowych z jej podobizną, pojawiała się także na opakowaniach papierosów, zapałek, zabawek i słodyczy. Jarzyna omawia w tym kontekście dwa wiersze: Epitafium dla Łajki Adama Włodka oraz Naprzód pies Zbigniewa Herberta, a także powiastkę Nicka Abadzisa Laika, we wszystkich tych utworach dostrzegając próby zawieszenia sensu "(nad)danego" śmierci suczki i w ten sposób przywracania jej podmiotowości [s. 383].

Część czwarta nosi tytuł Wspólny świat: od-nowa i jest poświęcona namysłowi „nad konwencjami opisów przyrody [...] i możliwościami przeformułowania ich w taki sposób, by nie skutkowały uprzedmiotowianiem" [s. 48]. Oprócz tego Jarzyna $\mathrm{w}$ tej części przypatruje się utworom opowiadającym o "międzygatunkowych relacjach opartych na wzajemności” [s. 48]. W rozdziale Ornitomancja, ornitologia zajmuje się przyrodniczym pisarstwem ornitologa Jana Sokołowskiego oraz jego podobieństwami z językiem poetyckim Jerzego Ficowskiego. Badaczka zauważa z jednej strony niebywałą poetyc- 
kość opisów ptasiego życia autorstwa profesora Sokołowskiego, a z drugiej jego nieantropocentryczne otwarcie $w$ obserwowaniu i opisywaniu ptaków. Wyjątkowe, że jako naukowiec, profesor traktuje każdego ptaka osobniczo: „odżegnuje się od uogólnień, od postrzegania jednostki przez pryzmat cech charakterystycznych dla danego gatunku, podkreśla indywidualne predyspozycje" [s. 413]. Pomimo ogromnej ornitologicznej wiedzy, badacz nie dał się pochłonąć optyce wyłącznie naukowej, a wręcz przeciwnie „oswobadzał ptaki z naukowego dyskursu, często uprzedmiotawiającego zwierzęta, nadmiernie ostrożnego $\mathrm{w}$ przyznawaniu im emocji i inteligencji" [s. 417]. Jarzyna zestawia wrażliwość profesora z poetycką wyobraźnią Ficowskiego, który w starożytnej sztuce ornitomancji dopatrywał się możliwości duchowego spotkania z innymi gatunkami [s. 421]. Obaj twórcy na swój sposób próbowali przywracać zwierzętom odebraną im przez kulturę duchowość i udowadniać, że „ich życie nie ogranicza się do wiązki instynktów” [s. 421]. W tym duchu napisany jest także kolejny rozdział o tytule Przekładając z ornitologicznego. O twórczości Michała Ksiażka, który pokazuje, jak poeta w swoich utworach znosi antroponormatywne opozycje, a w poezji widzi alternatywny wobec nauki język poznania i opisu przyrody [s. 453].

Rozdział ostatni, Gatunki rozkoszy, traktuje o tak zwanych zwierzętach towarzyszących, tych, z którymi jako ludzie nawiązujemy relacje, mieszkamy. Jarzyna przygląda się narracjom opowiadającym o wzajemnym ludzko-zwierzęcym języku bliskości, którego wyrazem są pieszczoty. Wyzwalające jest, jak zauważa badaczka, nie tylko demaskowanie opresji człowieka nad zwierzętami, ale także opisywanie pozytywnego wymiaru ich wspólnej egzystencji, dopełnia to bowiem obraz rzeczywistości, a także pomaga w odzyskiwaniu podmiotowości zwierząt, chroniąc przed ich wiktymizacją [s. 486]. Ważne jest też, by emocje takie jak radość, przywiązanie, czy tęsknotę, traktować równoprawnie w odniesieniu do człowieka i gatunków pozaludzkich, by „nie szukać [dla nich] osobnego miejsca w słownikach” [s. 505].

Książka Post-koiné Anity Jarzyny to lektura niezwykle interesująca i dostarczająca wielu inspiracji, a jej niezaprzeczalną zaletą jest erudycja autorki: imponująca ilość cytowanych dzieł, rozbudowanych przypisów i szeroka bibliografia. Omawiając poszczególne utwory i zagadnienia, badaczka włącza w rozmyślania zróżnicowane źródła z zakresu historii, filozofii czy nauk przyrodniczych, a także: ustawy państwowe, raporty organizacji prozwierzęcych, dokumenty kościelne, fragmenty podręczników weterynaryjnych, a także wiele innych. Autorka, zgodnie ze swoim założeniem, kreśli ekokrytyczną mapę problemową współczesnych narracji o zwierzętach, tworzy „możliwie szerokie spektrum” [s. 532] zagadnień z zakresu animal studies. Publikacja zawiera analizy punktowe, ale rzetelne i umożliwiające szeroki ogląd 
tematu. Badaczka przygląda się rozmaitym obszarom opresji wobec zwierząt: przemysłowi mięsnemu i futrzarskiemu, myślistwu, laboratoryjnym badaniom prowadzonym na zwierzętach, a także instytucjom reprodukującym zgodę na tę opresję, takim jak: szkoła, kościół, państwo, kultura czy nauka. Omawia języki poetyckie, bo jak twierdzi, to w nich właśnie odbija się język „zbiorowego imaginarium” [s. 353], z drugiej jednak strony zauważa, że język poetycki wyprzedza dyskursy postantropocentryczne, które bywają „niewystarczające, redukcjonistyczne, nie dość zniuansowane” [s. 531]. Poezja byłaby więc paradoksalnie zarazem odbiciem, jak i zwiastunem zmian zachodzących w wyobraźni wspólnoty, a omawiana książka próbą uważnego ich prześledzenia.

\section{Bibliografia}

Barcz Anna (2011), O ciele ekokrytycznie i z perspektywy queer, „Przegląd Filozoficzno-Literacki", nr 4, s. 215-231.

Barcz Anna (2012), Przyroda - bliska czy daleka? Ekokrytyka i nowe sposoby poetyki odpowiedzialności za przyrodę w literaturze, „Anthropos?”, nr 18-19, s. 59-79.

Barcz Anna (2013), Posthumanizm i jego zwierzęce odgłosy w literaturze, „Teksty Drugie”, nr 1-2, s. 60-79.

Barcz Anna (2014), „Moja przyjaciółka krowa” - o niesymbolicznej reprezentacji krowy u Julii Hartwig, Jolanty Brach-Czainy i Marlen Haushofer, w: Ludzie i zwierzęta, red. R. Chymkowski, A. Jaroszuk, Warszawa: Uniwersytet Warszawski, s. 101-116.

Barcz Anna (2015), Wprowadzenie do zookrytyki (teorii zwierzęcych narracji), „Białostockie Studia Literaturoznawcze", nr 6, s. 143-159.

Barcz Anna (2016), Realizm ekologiczny. Od ekokrytyki do zookrytyki w literaturze polskiej, Katowice: Wydawnictwo Śląsk.

Barcz Anna, Dąbrowska Magdalena [red.] (2014), Zwierzęta, gender, kultura. Perspektywa ekologiczna, etyczna i krytyczna, Lublin: E-naukowiec.

Barcz Anna, Łagodzka Dorota [red.] (2015), Zwierzęta i ich ludzie. Zmierzch antropocentrycznego paradygmatu?, Warszawa: Wydawnictwo Instytutu Badań Literackich PAN.

Filipowicz Anna (2017), (Prze)zwierzęcenia. Poetyckie drogi do postantropocentryzmu, Gdańsk-Sopot: Wydawnictwo Uniwersytetu Gdańskiego.

Jarzyna Anita (2019), Post-koiné. Studia o nieantropocentrycznych językach (poetyckich), Łódź: Wydawnictwo Uniwersytetu Łódzkiego.

Krupiński Piotr (2016), "Dlaczego gęsi krzyczały?” Zwierzęta i Zagłada w literaturze polskiej XX i XXI wieku, Warszawa: Wydawnictwo Instytutu Badań Literackich PAN.

Madejski Jerzy (2002), Przyboś ekokrytyczny?, w: Stulecie Przybosia, red. S. Balbus, E. Balcerzan, Poznań: Wydawnictwo Naukowe Uniwersytetu im. Adama Mickiewicza, s. 353-367. 
Mytych-Forajter Beata (2017), Zwierzęta na zakręcie, Warszawa: Wydawnictwo Instytutu Badań Literackich PAN.

Tabaszewska Justyna (2010), Jedna przyroda czy przyrody alternatywne? O pojmowaniu i obrazach przyrody w polskiej poezji, Kraków: Universitas.

Tabaszewska Justyna (2011), Zagrożenia czy możliwości? Ekokrytyka - rekonesans, „Teksty Drugie", nr 3, s. 205-220.

Woźniak Jarosław (2017), Widma ekokrytyki, „Przestrzenie Teorii”, nr 28, s. 169-191.

\title{
The Enlarged Community
}

\begin{abstract}
This article is a discussion of Anita Jarzyna's book Post-koine. Studia o nieantropocentrycznych jezzykach (poetyckich) [Post-koine. Studies of non-anthropocentric (poetic) languages] (2019), which analyses non-anthropocentric narratives in contemporary Polish poetry. The reviewer introduces the problematics of the monograph and notices the non-obvious choice of works interpreted by Jarzyna, who is primarily interested in glimpses of the non-anthropocentric perspective in authors not associated with the ecocritical writing. Taking into account various interpretative contexts, the author presents a wide spectrum of issues from the field of animal studies, and she also argues that poetry is both a reflection and a harbinger of changes that are taking place in the collective imagination.
\end{abstract}

Keywords: post-anthropocentrism, ecocriticism, animal studies, interspecies communication, anthropormative violence 